\title{
Strategi Pengembangan Kurikulum Menghadapi Tuntutan Kompetensi Abad 21
}

\author{
Ary Asy'ari' ${ }^{1}$, Tasman Hamami \\ ${ }^{1}$ FITK, Universitas Islam Negeri Sunan Kalijaga Yogyakarta, Indonesia \\ ${ }^{2}$ FITK, Universitas Islam Negeri Sunan Kalijaga Yogyakarta, Indonesia \\ 1aarryyasy@gmail.com
}

\begin{abstract}
Abstrak:
Tujuan dari penelitian ini adalah untuk mengetahui bagaimana strategi Pengembangan kurikulum dalam menghadapi tuntutan abad 21, pengembangan kurikulum atau curriculum planning menurut david pratt dan winarno surahmad lebih bersifat konseptual dibanding bersifat material yang meliputi aktivitas penyusunan, pelaksanaan, penilaian dan penyempurnaan kurikulum. Metode penelitian yang digunakan adalah studi kepustakaan atau studi literatur dengan mencari berbagai sumber data yang berasal dari buku dan artikel jurnal yang relevan yang berguna untuk memperkuat argumentasi penulis. Hasil penelitian menunjukan bahwa strategi pengembangan kurikulum dapat dilakukan dengan beberapa langkah yaitu: identifikasi kebutuhan, mencari bahan kurikulum, analisis bahan kurikulum, penilaian bahan kurikulum, pembuatan keputusan adopsi bahan kurikulum.
\end{abstract}

Kata Kunci: Kurikulum, Kompetensi, Abad 21.

\begin{abstract}
:
The purpose of this study is to find out how the curriculum development strategy in dealing with the demands of the 21st century, curriculum development according to David Pratt and Winarno Surahmad are more conceptual than material which includes the activities of compiling, implementing, evaluating and refining the curriculum. The research method in this research is the study of literature or literature studies by finding various sources of data derived from relevant books and journal articles that are useful to strengthen the argument of the author The results showed that the curriculum development strategy can be carried out with several steps, namely: identification of needs, searching curriculum materials, curriculum material analysis, curriculum material assessment, decision making adoption of curriculum material.
\end{abstract}

Keywords: Curriculum, Competence, 21th Century. 
Ary Asy’ari, Tasman Hamami

\section{Pendahuluan}

Perkembangan teknologi pada abad 21 dan lajunya ilmu pengetahuan mendorong manusia berubah pola hidupnya. Perubahan pola hidup ini terjadi pula dalam dunia pendidikan. Pendidikan tidak lagi berfungsi hanya untuk mentransfer ilmu pengetahuan saja, lebih dari itu pendidikan harus mampu menyiapkan peserta didik sebagai pelopor perubahan atau agen perubahan yang mempunyai kemampuan merubah segala aspek kehidupan, juga pendidikan dipersiapkan untuk mendidik generasi muda agar mempunyai kompetensi yang dubutuhkan di masa yang akan datang, kompetensi yang dibutuhkan tersebut berupa kepribadian yang berkarakter, baik dan mempunyai kemampuan unutk menghidupi diri sendiri, keluarga, masyarakat dan bangsa, lebih jauhnya lagi dapat mengembangkan kehidupan manusia. ${ }^{1}$

Kini, di abad ke 21 tantangan yang dihadapi indonesia adalah bagaimana mampu menghasilkan sumber daya manusia yang unggul dan berkualitas agar mampu bersaing di era globalisasi. Maka untuk mampu bersaing di era globalisasi tersebut pemerintah telah melakukan berbagai upaya untuk mewujudkan hal tersebut salah satunya melalui legislasi anggaran pendidikan yang mencapai $20 \%$ dari anggaran APBN, akan tetapi hal tersebut bukan menjadi jaminan pendidikan di indonesai akan maju dan bermutu. ${ }^{2}$ Indonesia harus benar benar berupaya semaksimal mungkin agar tujuan pendidikan nasional dapat tercapai..

Pendidikan yang bermutu dan berkeadilan dapat menunjukan kemandirian bangsa. ${ }^{3}$ Maka pendidikan harus dapat menjadi sarana pembangunan nasional dalam segala bidang. Dalam bidang ekonomi pendidikan sebisa mungkin harus menghasilkan seorang ekonom handal yang mampu mengatur perekonomian negara. Dalam bidang politik pendidkan harus menghasilkan output seorang politikus yang jujur, adil, inovatif dan terampil dalam menyelsaikan permasalahan bangsa.

Tentu tidaklah mudah mewujudkan hal demikian, langkah awal yang harus dilakukan adalah dengan memperhatikan pembangunan pendidikan nasional yang berlandaskan penelitian dan riset. Melalui penelitian dan riset itulah dapat diketahui potensi, tantangan dan peluang pada masa yang akan datang.

Dalam kaitan tersebut berikut akan terdapat dua permasalahan mendasar yang dihadapi dalam pengelolaan dan penyelenggaraan sistem pendidikan nasional. Pertama, berkenaan dengan daya saing bangsa, suatu negara dikatakan unggul adalah ketika tersedianya sumber

\footnotetext{
${ }^{1}$ Hamzah Uno, pengembangan kurikulum dan rekayasa pedagogik dalam pembelajaran (Depok: Rajawali Press, 2018), hal 3.

${ }^{2}$ Ace Suyadi, pendidikan indonesia menuju 2025, (Bandung: Remaja Rosda Karya, 2014), hal 3.

${ }^{3}$ Suyadi, hal 5 .
} 
daya manusia atau human resources yang mengusasai ilmu pengetahuan dan teknologi yang mendalam, ${ }^{4}$ maka seharusnya berbagai kebijakan pendidikan di indonesia dibuat agar mampu menghasilkan peserta didik yang faham ilmu pengetahuan dan teknologi, akan tetapi dewasa ini di indonesia terdapat kenyataan bahwa setiap kebijakan yang dibuat lebih berorientasi pada dua permasalahan pokok yaitu: pertama pembangunan pendidikan hanya berorientasi pada pengadaan sarana prasarana semata dengan membangun berbagai macam infrastruktur yang bertujuan untuk menampung semakin banyaknya peserta didik di suatu lembaga. Kedua kurang masksimalnya mutu proses pendidikan dan penyelenggaraan pendidikan yang ditandai dengan kurikulum yang hanya berorientasi pada nilai nilai akademik semata serta pengalokasian waktu dalam proses pembelajaran yang masih kurang bermutu.

Peningkatan mutu pendidikan harus mendapat perhatian yang sangat serius dari para pemerhati pendidikan, karena dengan peningkatan mutu inilah suatu lembaga pendidikan lebih jauhnya lagi suatu negara dapat disegani karena mampu bersaing dengan bangsa lainya. Disamping itu suatu lembaga yang bermutu ia akan mampu tetap eksis dan akan terus berkembang karena melakukan berbagai inovasi dan tetap menjaga kualitas pendidikan nya. Sebaliknya lembaga yang tidak memperhatikan mutu pendidikanya ia tidak akan mampu bersaing dengan lembaga lainya lebih jauhnya lagi suatu negara yang kualitas pendidikanya kurang bermutu tidak akan mampu bersaing dengan negara lainya, inilah penitngnya peningkatan mutu pendidikan. ${ }^{5}$

Selanjutnya muhammad wadjdi melanjutkan mutu terdiri dari beberapa karakteristik dintaranya: 1) kinerja fungsional sekolah yang maksimal, sebagai contoh guru dan karyawan sekolah bekerja secara maksimal dalam memberikan pelayanan. 2) waktu wajar, tidak terlalu cepat dan tidak terlalu lama, misalnya memulai pembelajaran tepat waktu sesuai dengan jam pelajaran yangtelah ditentukan. 3) reliability. Pelayanan sekolah memperhatikan aspek kualitas yang bertahan lama, misalnya pealayanan maksimal sekolah bertahan dalam waktu yang lama serta mutu sekolah tersebut tetap dari tahun ke tahun. 4) daya tahan (durability) misalnya dalam keadaan krisis sekolah masih mampu bertahan dan proses pembelajaran masih tetap berjalan. 5) indah, misalnya dari segi bangunan memiliki nilai estetika tersendiri sehingga enak dipandang, para guru dan karyawan berpenampilan rapi dll. 6) hubungan manusiawi, misalnya para karyawan sekolah bekerja dengan saling menghormati satu sama lainya, bersikap profesional dll. 7) mudah penggunaanya, dalamhal ini sarana prasarana yang ada di sekolah

\footnotetext{
${ }^{4}$ Sulaiman, "peningkatan mutu pendidikan dalam rangka meningkatkan daya saing perguruan tinggi untuk menghadapi era globalisasi," jurnal administrasi publik 5, no. 2 (2015): hal 46.

${ }^{5}$ Hilman Wadjdi, "manajemen peningkatan mutu lembaga pendiidkan islam" 1, no. 1 (2015): hal 45-46.
} 
mudah untuk dipakai. 8) mempunyai keunggulan yang khas, misalnya banyak alumni sekolah tersebut yang diterima di berbagai universitas bermutu. 9) memenuhi standar tertentu, misal standar minimal pelayanan,atau lebih jauhnya sekolah tersebut berstandar internasional. 10) konsistensi kualotas dari tahun ke tahun tetap stabil. 11) ketepatan dalam pelayanan.

Selain berkenaan dengan daya saing, permasalahan lain yang cukup mengkhawatirkan adalah angka pengangguran yang cukup tinggi. Bahkan dalam data badan pusat statistik jumlah pengangguran nasional sebesar 8,14\%.6 Bahkan ada kecenderungan yang konsisten yang terjadi selama 5 tahun terakhir bahwa semakin tinggi pendidikan semakin tinggi pula angka pengangguranya. Persentase pengangguran lulusan pendidikan dasar hanya sebesar1-3\%, lulusan sekolah menengah sebesar14\%, Ironisnya angka pengangguran tertinggi diderita oleh para lulusan SMK yakni 15,70\%, lulusan jenjang diploma 15,38\%, padahal kedua satuan pendidikan tersebut dirancang untuk menyiapkan lulusan yang siap bekerja.

Gejala pengangguran diatas menunjukan adanya permasalahan terkait dengan relevansi pendidikan. Bahwa pendidikan di indonesia masih belum relevan dengan kompetensi yang dibutuhkan oleh masyarakat dan dunia kerja serta pembangunan nasional lebih jauhnya. Padahal pengangguran justru akan menjadi cikal bakal permasalahan lainya seperti tindakan kriminal, kemiskinan, kenakalan bahkan lebih jauhnya jika pengangguran terus dibiarkan akan mengancam kedaulatan bangsa. ${ }^{7}$

Berdasarkan berbagai permasalahan diatas perlu kiranya diadakan suatu kajian yang mendalam dan khusus untuk mengantisipasi dan mengeksplorasi berbagai isu untuk dapat mewujudkan sistem pendidikan nasional yang bermutu dan berkualitas serta berdaya saing global. Salah satu yang menjadi perhatian adalah di bidang kurikulum khususnya pengembangan kurikulum, karena kurikulum merupakan hal paling pokok dalam penyelengaraan pendidikan. Maka penulis sangat tertarik melakukan penelitian tentang strategi pengembangan kurikulum menghadapi tuntutan abad 21 ini dengan harapan dapat memberikan sumbangsih baik secara teoritis ataupun praktiktis yang dapat memudahkan para pengembang kurikulum untuk menyusun dan mengembangkan kurikulum di masa mendatang.

Peneliti yang telah melakukan penelitian tentang pengembangan kurikulum sebelumnya adalah Syamsul Bahri, penelitianya berjudul pengembangan kurikulum dasar dan tujuanya. Dalam penelitian tersebut disebutkan ada 4 dasar yang menjadi acuan dalam pengembangan kurikulum diantaranya: dasar filosofis dan sejarah, dasar psikologis, dasar

\footnotetext{
${ }^{6}$ BPS, laporan survey angkatan kerja nasional (sakernas) tahun 2009 (Jakarta: Badan Pusat Statistik, 2009).

${ }^{7}$ Suyadi, pendidikan indonesia menuju 2025, hal 3.
} 
sosial budaya dan dasar IPTEK, sedangkan tujuan pengembangan kurikulum menurut syamsul bahri haruslah diesuaikan dengan tujuan institusional dengan memperhatikan kebutuhan yang ingin dicapai dalam satuan levelitas tertentu. ${ }^{8}$

Penelitian berikutnya ditulis oleh Karima Nabila Fajri dengan judul Proses Pengembangan Kurikulum, bahwa dalam penelitian tersebut disebutkan proses pengembangan kurikulum merupakan langkah untuk mengembangkan kurikulum atau menyempurnakan kurikulum yang sudah ada. Fokus dalam penelitianya adalah proses pengembangan kurikulum, tahapan tahapan pengembangan kurikulum, serta faktor pendukung dan penghambat dalam pengembangan kurikulum. Adapun tahapan pengembangan kurikulum menurut para ahli antara lain model administratif, Arich Lewy, model Roger Tyler, Beuchamp dan Taba ${ }^{9}$.

Penelitian dengan judul Dasar Pengembangan Kurikulum Menjadi Pengalaman Belajar dilakukan oleh Fahamato Lase pada tahun 2015, hasilnya dalam mengembangkan kurikulum ada hal yang harus diperhatikan diantaranya; tujuan pengembangan, tujuan pelajaran yang akan dicapai, materi pelajaran apa yang akan disampaikan, bagaiman amateri pelajaran itu disusun, dan bagaimana evaluasi untuk melihat apakah tujuan sudah tercapai. ${ }^{10}$

Penelitian dalam artikel ini berjudul Strategi Pengembangan Kurikulum menghadapi tuntutan kompetensi abad 21, kontribusi penelitian ini dapat membantu pengembang kurikulum untuk mengetahui langkah langkah sistematis yang telah disusun rapi dalam rangka untuk mengembangkan kurikulum.

\section{Metode Penelitian}

Metode penelitian dalam penelitian ini adalah penelitian kualitatif dengan teknik studi kepustakaan atau studi literatur dengan mencari berbagai sumber data yang berasal dari buku dan artikel jurnal yang relevan yang berguna untuk memperkuat argumentasi penulis. Analisis yang dilakukan dengan metode deskriptif analitik

\section{Pengertian kurikulum}

\footnotetext{
${ }^{8}$ Syamsul Bahri, "Pengembangan Kurikulum Dasar dan Tujuanya," jurnal ilmiah ISLAM FUTURA XI, no. 1 (2011).

${ }^{9}$ karima Nabila Fajri, "Proses Pengembangan Kurikulum," Islamika: Jurnal Keislaman dan Ilmu Pendidikan 1, no. 2 (2019).

${ }^{10}$ Fahamato Lase, “Dasar Pengembangan Kurikulum Menjadi Pengalaman Belajar,” Jurnal PG-PAUD STIKIP

Pahlawan Tuanku Tambusai 1, no. 2 (2015).
} 
Dalam pengertian harfiyah atau etimologis, kurikulum diambil dari bahasa Yunani yaitu curir yang mempunyai pengertian kata pelari dan curare yang mempunyai pengertian tempat berpacu. Jadi, istilah kurikulum ini pada jaman dahulu sering digunakan dalam dunia olahraga khususnya di romawi dan yunani kuno yang memiliki arti suatu jarak yang berasal dari garis start yang harus ditempuh oleh pelari hingga menuju garis finish.$^{11}$

Menurut S. Nasution, kurikulum ialah satu perencanaan dalam proses pembelajaran dengan cara menyusun berbagai hal yang mampu melancarkan proses pembelajaran, sekolah dan lembaga pendidikan bertanggungjawab penuh beserta semua stakeholder yang ada di lembaga pendidikan tersebut. Lebih jauh lagi nasution menjelaskan bahwa kurikulum bukan hanya kegiatan yang direncanakan semata tetapi meliputi semua peristiwa yang terjadi. Jadi selain ada kurikulum formal juga ada kurikulum informal (co-curriculum atau ekstra curriculum $)^{12}$. Sedangkan menurut Pratt dalam masrifa hidayani mengemukakan kurikulum adalah seperangkat tujuan yang dibuat oleh suatu lembaga formal maupun informal atau lembaga pelatihan. ${ }^{13}$

Selanjutnya Syamsul Bahri sebagaimana mengutip pendapat Alice Miel bahwa kurikulum tidak hanya sebatas rancangan program yang telah disusun sedemikian rupa melainkan juga meliputi suasana sekolah, keadaan gedung, keingninan, keyakinan, dan sikap dalam lingkungan sekolah tersebut. ${ }^{14}$ Senada dengan hal itu Muhaimin dan Abdul Mujib berpendapat bahwa kurikulum mempunyai beberapa pengertian berdasarkan fungsinya sendiri sendiri yaitu: pertama kurikulum sebagai program studi maksudnya berisi berbagai materi pembelajaran yang dipelajari dalam satuan pendidikan, kedua kurikulum sebagai konten maksudnya kurikulum memuat berbagai data yang terdapat dalam buku buku mata pelajaran tertentu yang memuat berbagai informasi, ketiga kurikulum sebagai kegiatan terencana maksudnya berisi sserangkaian kegiatan terstruktur dan sistematis yang dalam penyampaianya telah direncanakan terlebih dahulu. Keempat kurikulum sebagai hasil belajar maksudnya berisi hasil dari seperangkat kegiatan yang telah direncanakan, kelima kurikulum sebagai reproduksi kultural maksudnya kurikulum harus menjadi media untuk mentransfer nilai nilai kebudayaan dan norma yang berlaku di masyarakat, keenam kurikulum sebagai media pengalaman belajar maksudnya berisi pengalaman pengalaman belajar yang direncanakan, ketujuh kurikulum

\footnotetext{
${ }^{11}$ Hasan langulung, Manusia dan Pendidikan suatu Analisa Psikologi Pendidikan (Jakarta: Pustaka Al-Husna, 1986), hal 176.

${ }^{12} \mathrm{~S}$ Nasution, kurikulum dan pengajaran (Jakarta: rineka cipta, 1989), hal 5.

${ }^{13}$ Masrifa Hidayani, "model pengembangan kurikulum," At-Ta'lim 16, no. 2 (2017): hal 379.

${ }^{14}$ Bahri, "Pengembangan Kurikulum Dasar dan Tujuanya," hal 18.
} 
sebagai produksi maksudnya kurikulum berisi materi pembelajaran yang harus menghasilkan. 15

Jadi kurikulum merupakan keseluruhan program dan kegiatan yang disusun untuk mewujudkan tujuan pendidikan secara umum dan mewujudkan visi misi suatu lembaga secara khusus. Maka dalam implementasi kurikulum dalam rangka terwujudnya keberhasilan suatu lembaga sangat dipengaruhi oleh faktor-faktor pendukung diantaranya: guru atau karyawan yang berkompeten di bidangnya, fasilitas inti yang mendukung, adanya fasilitas bantu seperti laboratorium yang mumpuni, adanya dana yang memadai, adanya manajemen yang baik, serta kepemimpinan yang visioner transparan dan akuntabel. ${ }^{16}$

\section{Pengertian pengembangan kurikulum}

Curriculum development atau curriculum planning meliputi aktivitas penyusunan, pelaksanaan, penilaian dan penyempurnaan kurikulum. sehingga David Pratt dan Winarno Surahmad berpendapat pengembangan kurikulum lebih bersifat konseptual dibanding bersifat material. Pratt juga lebih memilih desain kurikulum (curriculum design) daripada pengembangan kurikulum alasanya desain lebih mengacu pada kegiatan tertentu dan seksama bukan pada evolusi atau pertumbuhan yang gradual. ${ }^{17}$ Maka dari itu pengembangan kurikulum dapat diartikan sebagai suatu rangkaian proses mulai dari perencanaan yang dilakukan oleh pengembang kurikulum kemudian penyusunan kurikulum oleh lembaga pengembang dan berbagai kegiatan yang dilakukan agar kurikulum yang dikembangkan dapat menjadi solusi pemecahan masalah yang ada dalam dunia pendidikan serta menjadi katalisator pembangunan pendidikan nasional lebih jauhnya.

Sedangkan Audrey nichols dan S.Howard Nichols berpendapat bahwa pengembangan kurikulum adalah is a set of learning plans that contain learning opportunities with the intention of bringing students in the direction of the desired changes and assessing the extent to which these changes occur in students. ${ }^{18}$ Artinya adalah kurikulum adalah seperangkat

\footnotetext{
15 Muhaimin dan Abdul Mujib, Pemikiran Pendidikan Islam Kajian Filosofis dan Kerangka Dasar operasionalnya (Bandung: Remaja Rosda Karya, 1993), hal 56.

${ }^{16}$ Hidayani, "model pengembangan kurikulum," hal 379.

${ }^{17}$ Hendra Kurniawan, kajian kurikulum dan bahan ajar sejarah SMA menurut kurikulum 2013 (Yogyakarta: sanata dharma university press, 2018), hal 30.

${ }^{18}$ Ruma Mubarok, “pengembangan kurikulum sekolah dasar,” MADRASAH 5, no. 2 (Juni 2013): hal 26.
} 
rencana pembelajaran yang berisi peluang belajar dengan tujuan membawa siswa ke arah perubahan yang diinginkan dan menilai sejauh mana perubahan ini terjadi pada siswa. ${ }^{19}$

Selanjutnya dalam mengembangkan kurikulum perlu menilai dan menyeleksi bahan bahan kurikulum tersebut, Menurut Gall bahan kurikulum yang dimaksud adalah is something that has physical properties, the nature of representation and that is used to facilitate the learning process. So the school curriculum development has not yet been declared complete if the curriculum or learning material has not been determined, yang artinya materi kurikulum adalah sesuatu yang memiliki sifat fisik, sifat representasi dan yang digunakan untuk memperlancar proses pembelajaran. Jadi pengembangan kurikulum sekolah belum dinyatakan lengkap jika kurikulum atau materi pembelajaran belum ditentukan. ${ }^{20}$

Entiti fisik (physical entities) yang dimaksud adalah wujud dari bahan kurikulum itu nampak adanya, bukan berupa gagasan atau ide ide semata atau konsep. ${ }^{21}$ Contoh bahan kurikulum yang dapat diobservasi yaitu media cetak, film, buku buku, artikel artikel jurnal, hasil penelitian dan lain-lain. selanjutnya Perlu juga menganalisis bahan kurikulum yang dapat menyampaikan sesuatu yang lebih dari sekedar barangnya itu sendiri. ${ }^{22}$ Misalnya buku sejarah, dalam wujud fisiknya buku sejarah tersebut tidak memiliki arti pengajaran,akan tetapi buku sejarah tersebut mempunyai isi yang dianggap bahan pengajaran karena menyampaikan berbagai peristiwa-peristiwa sejarah yang terjadi di masa lampau.

Dalam mengembangkan kurikulum tentunya harus memperhatikan landasan landasan utama dalam pengembangan kurikulum, Purwadih dalam penelitianya menyebutkan setidaknya ada empat landasan yang dijadikan pedoman dalam pengembangan kurikulum, diantaranya: philosophical foundation, psychological foundation, social cultural foundation and foundation of the development of science and technology. ${ }^{23}$ Sedangkan prinsip dalam pengembangan kurikulum yaitu: prinsip relevansi maksudnya isi kurikulum yang akan dikembangkan harus mempunyai relevansi baik secara internal kurikulum itu sendiri maupun secara eksternal yang harus memiliki relevansi dengan tuntutan abad ke 21, prinsip fleksibilitas maksudnya kurikulum yang dikembangkan harus menjawab kebutuhan berdasarkan situasi dan kondisi yang terjadi, prinsip kontinuitas yakni adanya kesinambungan atau keterkaitan antara

\footnotetext{
${ }^{19}$ Ahmad Taufik, “pengemmbangan kurikulum pendiidkan islam,” el-ghiroh XVII, no. 2 (2019): hal 86.

${ }^{20}$ Burhan Nurgiantoro, Dasar-Dasar Pengembangan Kurikulum Sekolah (Yogyakarta: BPFE, 1988), hal 84.

${ }^{21}$ Nurgiantoro, hal 84.

${ }^{22}$ Nurgiantoro, hal 85.

23 Purwadih, "pengembangan kurikulum dalam pembelajaran abad XXI," MIMBAR PENDIDIKAN: jurnal indonesia untuk kajian pendidikan 4, no. 2 (2019): hal 104.
} 
kurikulum pada satu tingkat pendidikan dengan tingkat pendidikan lainya sehingga materi yang diajarkan dalam kurikulum tersebut tidak terjadi pengulangan ,prinsip efisiensi yakni kurikulum yang dikembangkan sesuia dengan tujuan, prinsip efektivitas yakni isi materi dari kurikulum yang dikembangkan dapat dengan mudah disampaikan oleh pendidik dan dengan mudah difahami oleh peserta didik. ${ }^{24}$

\section{Pengertian kompetensi}

Definisi kompetensi menurut peraturan pemerintah no 32 tahun 2013 pada pasal 1 ayat 4 berbunyi “ kompetensi sikap, pengetahuan dan keterampilan yang harus dimiliki dan dikuasai oleh peserta didik setelah mempelajari suatu muatan pembelajaran menamatkan suatu program atau menyelesaikan satuan pendidikan.

Siti zubaidah menyebutkan setidaknya ada sepuluh kompetensi yang harus dimiliki oleh setiap peserta didik agar ia mampu bersaing di abad ke 21 ini, kompetensi tersebut yaitu keterampilan critical thinking, comunication , leadership, colaboration, adaptability, productivity dan accountability, inovation, global cityzensip, entrepreneurship, serta ability to access, analyze and synthesiz the information. ${ }^{25}$ Kompetensi yang menjadi tuntutan di masa depan tersebut menjadi harga mati yang harus dimiliki oleh setiap individu agar ia mampu bersaing dengan individu lainya.

\section{Strategi pengembangan Kurikulum}

Pengembangan kurikulum sebagai suatu hal yang sangat penting 26 maka memerlukan strategi dalam pengembanganya agar kurikulum yang dikembangkan betul betul berkualitas maka Tahap awal dalam strategi pengembangan kurikulum adalah dengan memproses adopsi bahan kurikulum yang tentunya bisa berasal dari mana saja sehingga bahan yang diperoleh bervariasi tergantung siapa yang memperoleh dan dari mana bahan tersebut diperoleh. Apabila penyeleksian dilakukan untuk diri kita sendiri maka dilakukan secara informal, walaupun

\footnotetext{
${ }^{24}$ Shofiyah, "prinsip-prinsip pengembangan kurikulum dalam upaya meningkatkan kualitas pembelajaran," EDURELIGIA: jurnal pendidikan agama islam 2, no. 2 (2018): hal 128-129.

${ }^{25}$ Siti Zubaidah, "keterampilan abad 21: keterampilan yang diajarkan melalui pembelajaran," keterampilan abad 21: keterampilan yang diajarkan melalui pembelajaran, 25 Maret 2020, https://www.researchgate.net/publication/318013627_KETERAMPILAN_ABAD_KE-

21_KETERAMPILAN_YANG_DIAJARKAN_MELALUI_PEMBELAJARAN.

26 Subandi, "pengembangan kurikulum 2013 (studi analisis subtantif kebijakan kurikulum nasional," ), TERAMPIL: jurnal pendidikan dan pembelajaran dasar 1, no. 1 (2014): hal 19.
} 
prosesnya tetap secara sistematis, didokumentasikan pada setiap langkah dan dicekkan oleh orang lain serta dapat dipertanggungjawabkan. Sedangkan apabila penyeleksian untuk orang lain maka proses tersebut dilakukan secara formal, dan tentunya dengan tahap-tahap tertentu yang dapat dipertanggungjawabkan. Adapun proses tahapan yang dilakukan untuk menyeleksi bahan kurikukulum secara formal, yaitu:

\section{Identifikasi Kebutuhan (Identify Your Needs)}

Hal pertama dalam proses penyeleksian bahan kurikulum adalah mengidentifikasi kebutuhan, dalam hal ini para ahli mengemukakan bahwa kebutuhan adalah ketidaksesuaian antara kenyataan dan keinginan. Hal ini dapat ditandai dengan kurangnya bahan bahan ajar untuk mencapai tujuan pengajaran. Sebagai contoh terdapat beberapa sekolah yang menggunakan bahan pembelajaran seperti buku yang tidak sesuai dengan zamannya, seperti menggunakan buku terbitan delapan belas tahun yang lalu. Sehingga tujuan yang diinginkan tidak tercapai. Untuk menutupi hal tersebut perlu mengadakan bahan bahan ajar baru yang disesuaikan dengan kebutuhan. Akan tetapi dalam proses pengadopsian bahan baru pun perlu penyeleksian yang ketat. Pemilihan bahan hendaknya dilakukan oleh tim penyeleksi. Tahapan yang dilakukan oleh tim penyeleksi diantaraya: 1) mendaftar bahan ajar yang digunakan yang dirasa kurang relevan dengan kebutuhan. 2) melakukan penelitian yang bertujuan untuk menyeleksi dan menilai bahan ajar baru yang telah diperoleh. Bahan baru tersebut haruslah mencerminkan visi dan misi lembaga pendidikan tersebut. ${ }^{27}$

\section{Mencari dan memperoleh Bahan Kurikulum (Access to Curriculum Materials)}

Cara kerja dari mendapatkan bahan kurikulum sebaiknya pengembang mencari dan mengelompokan bahan yang berkaitan dengan kebutuhan lembaga tersebut. ${ }^{28}$ Kesulitanya banyak pengembang dalam hal ini pendidik yang merasa kesulitan mencari bahan tersebut karena kurangnya informasi tentang bagaimana memperolehnya.

Dalam proses mencari dan memperoleh bahan kurikulum tersebut pengembang kurikulum yang dalam hal ini pendidik harus secara aktif melakukan terobossan dan berinovasi serta terus mencari sampai menemukan bahan ajar yang relevan. Maka dalam prosesnya memang menuntut kerja yang sistematis. Sumber utama bahan tersebut bisa berasal dari bukubuku, jurnal, penelitian dan sebagainya. Jika sudah berhasil menemukan bahan tersebut maka

\footnotetext{
${ }^{27}$ Nurgiantoro, Dasar-Dasar Pengembangan Kurikulum Sekolah, hal 88.

${ }^{28}$ Gall meredith Damien, handbook for evaluation and selecting curriculum materials (Boston: Allyn And Bacon, 1981), hal 33 .
} 
bahan kemudian dikumpulkan, dicatat dan digunakan untuk menggantikan bahan lama yang sudah tidak dipakai karena tidak relevan. ${ }^{29}$

3. Analisis bahan (anylize the materials)

Analisis adalah suatu kegiatan yang dalam hal ini memisahkan berbagai bahan materi menjadi bagian bagian kecil untuk kemudian diuji tiap bagian itu serta apakah berkaitan satu sama lain atau tidak. ${ }^{30}$

Daftar analisis bahan tersebut dikelompokan kedalam empat kategori:

a. Publikasi dan informasi. Analisis dalam hal ini meliputi: 1) pengarang: siapa yang menulis bahan tersebut, apa latar belakang profesinya dan sebgainya. 2)awal mula atau sejarah bagaimana proses produksi bahan tersebut. 3) Edisi, 4) tanggal dan tahun publikasi 5) penerbit.

b. Kelayakan fisik material. Kelayakan fisik ini meliputi: 1) komponen materi apakah masih layak atau tidak, 2) daya tahan, apakah bahan itu masih kuat Dsb, 3) format media yang meliputi font yang digunakan apakah menarik untuk dibaca, penggunaan gambar sebagai ilustrasi Dsb, dan 4) kualitas.

c. Isi bahan. Hal terpenting dalam kurikulum adalah isi, bahkan kebanyakan para ahli berpendapat bahwa isi tidak lain adalah kurikulum itu sendiri, isi dari kurikulum biasanya memuat tentang fakta, konsep, generalisasi, keterampilan, berbagai teori teori yang terdapat dalam bahan. Isi dari bahan kurikulum ini haruslah dianalisis, namun sebagai pengembang haruslah berhati hati dalam mencari dan menentukan tujuan dan sikap apa yang akan dihasilkan dari bahan yang diperoleh. Berikut kami uraikan sub bagian dari isi:

1). Pendekatan: dalam hal ini dapat diajukan beberapa pertanyaan seperti apakah pendekatan yang dilakukan sudah sudah jelas pendahuluanya, apakah sudah sesuaidengan filsafat pendidikan dan lain sebagainya.

2).Tujuan pengajaran: adalah hasil belajar atau output peserta didik setelah bahan ini diterapkan . Dalam hal ini dapat diajukan beberapa pertanyaan seperti apakah tujuan sudah dirumuskan dengan sejelas-jelasnya atau belum, apakah tujuan tersebut ssesuai dengan visi danmisi lembaga, apakah tujuan yang dirumuskan sudah dalam bentuk tingkah laku dan sebagainya.

\footnotetext{
${ }^{29}$ Nurgiantoro, Dasar-Dasar Pengembangan Kurikulum Sekolah, hal 88.

${ }^{30}$ meredith Damien, handbook for evaluation and selecting curriculum materials, hal 41.
} 
3). Jenis jenis tujuan pengajaran: dalam hal ini mengacu pada taksonomi bloom yaitu meliputi ranah kognitif, afektif dan psikomotorik.

4). Orientasi masalah: maksudnya adalah bahan atau isi materi harus berjenis pemecahan masalah.

5). Multikultularisme, bahan yang dipakai memiliki keberagaman yang dapat meningkatkan kemampuan dan menambah wawasan peserta didik.

6). Cakupan dan urutan: maksudnya dari segi adequasi apakah materi dari bahan tersebut materinya sudah sangat luas dan topik bahan yang disajikan dan bagaiamana urutanya.

d. Kelayakan bahan untuk pengajaran. Analisis dalam kategori ini merupakan langkah yang paling kompleks, terstruktur dan sistematis dan tentu tidak mudah untuk dilakukan. Komponen untuk menganalisis nya pun sangatlah banyak, diantaranya:

1). Alat penilaian: yaitu alat yang digunakan untuk mengukur output belajar siswa. Alat yang dimaksud bisa berupa tes, atau tugas tugas lainya.

2). Kemudahn untuk difahami: maksudnya materi dari bahan yang disajikan dapat dengan mudah difahami oleh setiap siswa atau tidak.

3). Ada hubunganya dengan bahan kurikulum yang lain.

4). Efektifitas pengajaran: bahan ajar yang dipakai harus mempunyai bukti bahwa jika diterapkan akan efektif.

5). Langkah langkah pengajaran: merupakan serangkaian aktifitas kegiatan yang dilakukan oleh guru dan siswa dalam mempelajari suatu bahan ajar. Biasanaya analisis dalam hal ini tidak terlalu sulit karena hanya akan terdiri dari beberapa urutan saja. Hal itu disebabkan walaupun bahan ajar yang disajikan panjang tetapi akan terjadi pola pengulangan-pengulangan pola.

6). Sistem pengelolaan: yaitu prosedur yang dibuat unutk memantau proses penilaian dan mengontrol penggunaan bahan yang disertakan dalam perangkat bahan.

7). Prerekuisit: sesuatu hal yang harus dimiliki oleh peserta didik sebelum mempeljarai materi tertentu.

8). Kegiatan murid: segala aktifitas yang dilakukan oleh pesera didik.

9). Peran guru: tergantung dari metode yang digunakan, jika yang digunakan adalah metode ceramah maka guru berperan sangat dominan, tetapi dalam pembelajaran terprogram pran guru menjadi tidak terlalu signifikan. 
4. Penilaian bahan kurikulum.

Setelah kegiatan menganalisis bahan kurikulum yang secara sistematis telah dipaparkan diatas selanjutnya kita melakukan penilaian terhadap kurikulum untuk menilai kelayakanya. Strategi untuk penilaian kurikulum ini dapat dilakukan melalui dua cara:pertama memeriksa kelengkapan bahan tersebut, kedua membaca review kritik atau laporan dari studi evaluasi yang dilakukan oleh evaluator terhadap bahan yang akan kita pakai dan melakukan tes dengan cara melakukan uji coba di lapangan. ${ }^{31}$

5. Pembuatan keputusan adopsi bahan.

langkah terakhir dalam proses strategi pengembangan kurikulum adalah pembuatan keputusan untuk mengadopsi bahan. Masalah yang sering timbul adalah apabila para anggota tim penyeleksi bahan tidak mempunyai kesamaan pandangan mengenai bahan mana yang harus diadopsi. Maka untuk menyelesaikan masalah tersebut dapat ditempuh dengan memeringkat bahan-bahan yang berbeda tersebut kemudian bahan yang memperoleh rata-rata tertinggi adalah bahan yang harus disetujui oleh tim adopsi untuk selanjutnya diadopsi dan diterapkan. Cara selanjutnya adalah dengan melakukan pendekatan yang bersifat konsensus terhadap bahan-bahan yang berbeda itu dengan cara ini para anggota tim mendiskusikan bahan-bahan yang dimaksud untuk menemukan kelebihan dan kelemahan masing-masing untuk akhirnya mereka memutuskan salah satu bahan yang dinyatakan terbaik.

\section{Kesimpulan}

Kesimpulan dalam artikel ini bahwa pengembangan kurikulum merupakan suatu hal yang sangat diperlukan guna menjawab berbagai tantangan di abad ke 21 dan guna memenuhi kebutuhan masyarakat sesuai dengan kompetensi yang dibutuhkan, pengembangan kurikulum sebagai suatu hal yang sangat urgensif tidak hanya merupakan perwujudan dari setiap konsep atau ide ide yang muncul semata, melainkan harus mencerminkan suatu tindakan yang menghasilkan problem solve agar tujuan dari pengembangan kurikulum tersebut dapat terpenuhi. Selanjutnya untuk menjawab kesenjangan relevansi pendidikan dengan kebutuhan maka pemerintah harus melakukan restrukturisasi sistem pendidkan pada satuan pendidikan smk dan vokasi yaitu sistem pendidikan yang komprehensif dalam satuan mekanisme yang sistematik dalam semua aspek, misalnya resinkronisasi kurikulum antara penyelengara pendidikan dengan berbagai lembaga sebagai pemakai yang tetap memperhatikan kerangka

\footnotetext{
${ }^{31}$ Nurgiantoro, Dasar-Dasar Pengembangan Kurikulum Sekolah, hal 88.
} 
kualifikasi nasional indonesia (KKNI) agar dapat menghasilkan tenaga terdidik yang siap kerja sesuai dengan kebutuhan industri.

Kaitanya dengan peningkatan mutu pendidikan maka langkah yang harus dilakukan oleh pemerintah tidak hanya berfokus pada pembagunan sarana prasarana semata, tetapi juga harus meningkatkan kualitas guru dengan memberikan berbagai pelatihan pelatihan. Kegiatan pelatihan tersebut sangat penting untuk meningkatkan kompetensi guru.

Upaya untuk meningkatkan mutu pendidikan harus dilakukan oleh berbagai stakeholder pendidikan mulai dari pemerintah hingga masyarakat, dalam hal ini pemerintah bertugas merancang berbagai kebijakan, menyusun tujuan pendidikan, standar kompetensi dll, sedangkan masyarakat bertugas mendukung secara penuh dan menjalankan kebijakan tersebut serta meningkatkan partisipasinya untuk mensuskseskan pendidikan. kedua untuk meningkatkan relevansi pendidikan dengan kebutuhan lebih mengarah kepada efisiensi pendidikan itu sendiri dengan cara memperbaiki penataan kurikulum yang berbasis kompetensi dan berkarakter sehingga menghasilkan output peserta didik yang relevan dengan kebutuhan, dalam hal ini lembaga pendidkan berperan besar dalam meningkatkan sumber daya manusia yang dimilikinya demi tercapainya tujuan pendidikan tersebut, ketiga pemerataan pendidikan mengarah kepada pendidikan yang berkeadilan. Terakhir pendidikan harus berkarakter agar mampu menunjukan jati diri bangsa Indonesia. ${ }^{32}$

\section{Saran}

Adapun saran dari penelitian ini peneliti tujukan kepada beberapa pihak. Pertama kepada pembuat kebijakan dalam hal ini pemerintah sebelum melakukan perubahan kurikulum hendaknya betul betul memperhatikan segala aspek seperti kesiapan guru, kesiapan sarana prasarana, dan fasilitas penunjang lainya. Kemudian dalam pengembangan kurikulum pemerintah diharapkan mampu menyusun dan mengembangkan kurikulum yang relevan dengan kebutuhan masyarakat. Selanjutnya, kepada pendidik dalam rangka meningkatkan mutu pendidikan maka sebaiknya memperbanyak literasi dan memperbanyak mengikuti pelatihan pelatihan yang diperlukan guna meningkatkan profesionlisme dalam mengajar.

Terakhir, penelitian ini masih belum sempurna dan hanya sebatas penelitian pustaka, maka kepada peneliti yang akan melakukan penelitian dalam hal pengembangan kurikulum sebaiknya melakukan penelitian tentang pengembangan kurikulum dengan studi lapangan.

\footnotetext{
${ }^{32}$ E Mulyasa, Pengembangan dan Implementasi Kurikulum 2013 (Bandung: Remaja Rosda Karya, 2014), hal 5. 32 | IQ (Ilmu Al-qur'an): Jurnal Pendidikan Islam| Volume 3 No.01 2020
} 


\section{Daftar Pustaka}

Bahri, Syamsul. "Pengembangan Kurikulum Dasar dan Tujuanya." jurnal ilmiah ISLAM FUTURA XI, no. 1 (2011).

BPS. laporan survey angkatan kerja nasional (sakernas) tahun 2009. Jakarta: Badan Pusat Statistik, 2009.

Damien, Gall meredith. handbook for evaluation and selecting curriculum materials. Boston: Allyn And Bacon, 1981.

Hidayani, Masrifa. "model pengembangan kurikulum.” At-Ta'lim 16, no. 2 (2017): 379.

langulung, Hasan. Manusia dan Pendidikan suatu Analisa Psikologi Pendidikan. Jakarta: Pustaka Al-Husna, 1986.

Lase, Fahamato. "Dasar Pengembangan Kurikulum Menjadi Pengalaman Belajar.” Jurnal PGPAUD STIKIP Pahlawan Tuanku Tambusai 1, no. 2 (2015).

Mubarok, Ruma. "pengembangan kurikulum sekolah dasar." MADRASAH 5, no. 2 (Juni 2013). Muhaimin, dan Abdul Mujib. Pemikiran Pendidikan Islam Kajian Filosofis dan Kerangka Dasar operasionalnya. Bandung: Remaja Rosda Karya, 1993.

Mulyasa, E. Pengembangan dan Implementasi Kurikulum 2013. Bandung: Remaja Rosda Karya, 2014.

Nabila Fajri, karima. "Proses Pengembangan Kurikulum." Islamika: Jurnal Keislaman dan Ilmu Pendidikan 1, no. 2 (2019).

Nasution, S. kurikulum dan pengajaran. Jakarta: rineka cipta, 1989.

Nurgiantoro, Burhan. Dasar-Dasar Pengembangan Kurikulum Sekolah. Yogyakarta: BPFE, 1988.

Purwadih. "pengembangan kurikulum dalam pembelajaran abad XXI." MIMBAR PENDIDIKAN: jurnal indonesia untuk kajian pendidikan 4, no. 2 (2019): 104.

Shofiyah. "prinsip-prinsip pengembangan kurikulum dalam upaya meningkatkan kualitas pembelajaran.” EDURELIGIA: jurnal pendidikan agama islam 2, no. 2 (2018): 12829.

Subandi. "pengembangan kurikulum 2013 (studi analisis subtantif kebijakan kurikulum nasional." ), TERAMPIL: jurnal pendidikan dan pembelajaran dasar 1, no. 1 (2014).

Sulaiman. "peningkatan mutu pendidikan dalam rangka meningkatkan daya saing perguruan tinggi untuk menghadapi era globalisasi." jurnal administrasi publik 5, no. 2 (2015).

Suyadi, Ace. pendidikan indonesia menuju 2025, . Bandung: Remaja Rosda Karya, 2014.

Taufik, Ahmad. "pengemmbangan kurikulum pendiidkan islam." el-ghiroh XVII, no. 2 (2019): 86.

Uno, Hamzah. pengembangan kurikulum dan rekayasa pedagogik dalam pembelajaran. Depok: Rajawali Press, 2018.

Wadjdi, Hilman. "manajemen peningkatan mutu lembaga pendiidkan islam" 1, no. 1 (2015): 45-46.

Zubaidah, Siti. "keterampilan abad 21: keterampilan yang diajarkan melalui pembelajaran." keterampilan abad 21: keterampilan yang diajarkan melalui pembelajaran, 25 Maret 2020.

https://www.researchgate.net/publication/318013627_KETERAMPILAN_ABAD_K E-21_KETERAMPILAN_YANG_DIAJARKAN_MELALUI_PEMBELAJARAN. 
Ary Asy’ari, Tasman Hamami

34 | IQ (Ilmu Al-qur'an): Jurnal Pendidikan Islam| Volume 3 No.01 2020 